\title{
The Ideal 'Native Speaker' Teacher: Negotiating Authenticity and Legitimacy in the Language Classroom
}

\author{
ANGELA CREESE \\ MOSAIC Centre for Research on Multilingualism \\ University of Birmingham \\ School of Education \\ Edgbaston, Birmingham \\ B15 2TT, UK \\ Email:a.creese@bham.ac.uk \\ ADRIAN BLACKLEDGE \\ Director, MOSAIC Centre for Research on \\ Multilingualism \\ University of Birmingham \\ School of Education \\ Edgbaston, Birmingham \\ B15 2TT, UK \\ Email: a.j.blackledge@bham.ac.uk
}

\author{
JASPREET KAUR TAKHI \\ MOSAIC Centre for Research on Multilingualism \\ University of Birmingham \\ School of Education \\ Edgbaston, Birmingham \\ B15 2TT, UK \\ Email: j.takhi@bham.ac.uk
}

\begin{abstract}
This article presents a linguistic ethnographic study of a Panjabi complementary school in Birmingham, UK. Researchers observed classes for one academic year, writing field notes, conducting interviews, and making digital audio recordings of linguistic interactions. Sets of beliefs about the production and deployment of certain linguistic signs were powerfully in play in the language learning classroom, as teachers and students negotiated what counts as the authenticity and legitimacy of the 'native speaker' teacher. Analysis of examples from empirical linguistic material focuses on the ways in which local practices constitute, and are related to, orders of indexicality and language ideologies. Analytical discussion offers an understanding of complex, situated, and nuanced negotiations of power in claiming and assigning authenticity and legitimacy in language learning contexts. The article considers the construction of the 'native speaker' heritage language teacher, and asks what counts as authentic and legitimate in teaching the community language, Panjabi, to a group of English-born young people who share Panjabi as a cultural and linguistic heritage.
\end{abstract}

Keywords: native speaker; legitimacy; authenticity; negotiation; complementary schools; Panjabi

The Modern Language Journal, 98, 4, (2014)

DOI: $10.1111 / \bmod 1.12148$

0026-7902/14/937-951 \$1.50/0

(C) 2014 The Authors. The Modern Language Journal published by Wiley Periodicals, Inc. on behalf of the National Federation of Modern Language Teachers Associations, Inc.

This is an open access article under the terms of the Creative Commons Attribution-NonCommercial-NoDerivs License, which permits use and distribution in any medium, provided the original work is properly cited, the use is non-commercial and no modifications or adaptations are made. 


\section{LANGUAGE TEACHING HAS ALWAYS} worked with benchmarks that determine what counts as authentic language use. The notion of the authentic native speaker teacher is a persistent, if not uncontested, one. This ideological construction (Holliday, 2006) positions the native speaker teacher as the possessor of the right cultural and linguistic attributes to represent the target speech community. In English foreign language teaching markets, the authenticity, legitimacy, authority, and marketability of the native speaker teacher stands in contrast to the nonnative speaker teacher, whose credentials against these native speaker teacher benchmarks are often viewed as quasi and inauthentic. Critiques of the native speaker/nonnative speaker distinction have been levelled at the globalised industry of English language education, in which "the native speaker fallacy" (Phillipson, 1992) has led to stratifying distinctions with economic, political, and social consequences. Much less attention has been paid to the construction of native speakerism (Holliday, 2006) in other language teaching markets and local economies. This article considers the construction of the 'native speaker' heritage language teacher, and asks what counts as authentic and legitimate in teaching the community language, Panjabi, to a group of English-born young people who share Panjabi as a cultural and linguistic heritage. In a language classroom, a teacher and teaching assistant work with a group of young people preparing to take a General Certificate of Secondary Education $(\text { GCSE })^{1}$ examination in Panjabi. In a context where both adults may be categorized as native speakers of Panjabi, what counts as authentic is negotiated in interactions from moment to moment, as students and teachers contest degrees of authenticity and legitimacy.

In this article, we demonstrate that English has high status in the local language ecology of the Panjabi classroom. The high status of English is reflected in the hegemonic use of the term native speaker, which in discussions of language teaching and learning often refers only to the native speaker of English. The concept of the native speaker only has social resonance when it signposts speakers of economically powerful languages with a secure national base. It appears to have little meaning, or a different meaning, when it describes a teacher engaged in teaching a minority language to a minority ethnic group. We suggest that, in the heritage language classroom, the notion of the native speaker teacher is contested, as its value is questioned and made more complex. Here it is the bilingual teacher who is valued, her linguistic repertoire pointing not to simple purities but to complex migrations, mobilities, and histories, many of which are shared with the young people she teaches.

\section{THE NATIVE SPEAKER}

Doerr (2009) points out that in research in both second language acquisition and English language teaching there has been a tendency to treat native speakers and nonnative speakers as homogeneous groups. The native speaker/nonnative speaker dichotomy has been challenged by a number of scholars (Cenoz \& Gorter, 2011; Cook, 1999, 2007; Holliday, 2006; Kubota, 2009; Leung, Harris, \& Rampton, 1999; Rampton, 1990). Piller (2001, p. 14) speaks of a "useless," "debilitating," and "unfair" idealisation of the native speaker, which should be discarded. However, in the realm of language teaching, the notion of the authentic native speaker continues to hold sway. Here the native speaker thrives as a model, a norm, and a goal in teaching second and foreign languages. Kubota (2009) argues that the consensus in the field of English language teaching is that native speaker teachers supply the linguistic model, while nonnative teachers may possess attributes that can offset their linguistic weaknesses. In recent times, the attributes of the nonnative speaker teacher have been recognized as a positive model of the successful language learner and as more in touch with their students than the native speaker teacher. However, such an acknowledgment leaves intact the assumption that native speaker teachers are superior to nonnative speaker teachers due to their superior linguistic proficiency.

Doerr (2009) proposes that three ideologies underpin the concept of the native speaker: (a) There is a close correspondence between being a citizen of a nation state and being a native speaker of the national language; (b) language is a homogeneous and fixed system with a homogeneous speech community; and (c) being a native speaker automatically endows one with a high level of competence in all domains of one's first language. Doerr proposes a move away from such static beliefs, to examine the diversity among native speakers and the permeability of the border between native speakers and nonnative speakers. Kubota (2009) demonstrates that discussions of native speakerness frequently fail to take account of how social contexts and other social processes influence teachers' experiences. An approach that situates speakers in their social 
context allows us to understand the intersections of the native/nonnative speaker, and recognises the heterogeneity among (so-called) native speakers of various languages. It is worth quoting Kubota at length:

The recognition of multiple contexts and social categories that intersect with the linguistic dimension of native/nonnativeness raises questions of who/what is considered to be the social norm in a particular context, how power relations shift depending on who the participants are in the context, and the relative status of the language in a specific power hierarchy, and where resistance exists. (Kubota, 2009, p. 233)

Kubota argues that an understanding of the dynamics of language teaching would benefit from a perspective which engages with competing discourses, and which views specific social spaces as potential sites of struggle and contestation. That is, a comprehensive view of the language teacher should attend not merely to the relative native-like proficiency of the teacher, but to the social context, power relations, and ideologies in play.

\section{AUTHENTICITY AND LEGITIMACY}

Blommaert and Varis (2011) demonstrate that authenticity may be constituted in specific arrangements or configurations of emblematic features. Such features are recognisable, and as such may reflect, bestow, and emphasize membership and belonging. For example, discourses of identity-as-heritage may be recognised as discourses in which a particular configuration of features reflects and emanates images of unbroken, trans-generational transmission of traditions, timeless essentials, and reproduction of that which is already there. Demonstration of proficiency in emblematic features of a heritage language may be sufficient for an individual to be positioned as an authentic speaker of that language, and an authentic member of the heritage group. Among other things, appearance (the right clothes, hairstyle, make-up, tattoo), possessions (the right car, skateboard, mobile phone, shoes), and behaviour (the right kiss on greeting, way of [not] holding hands, way of walking down the street, way of eating) all constitute features that are evaluated in relation to authentic membership. But such arrangements and configurations are rarely static, either in time or place. Rather, Blommaert and Varis (2011) view authenticity as "dynamic processes which involve conflict, contestation and reinvention" (p. 4). That is, authenticity and legitimacy are negotiated from moment to moment, and are subject to local and global contingencies.

A significant type of emblematic feature, which may bestow authenticity and legitimacy, is the linguistic. Gill (2007) notes that the authenticity of the native speaker is an idealization, with the unreflectingly fluent and competent language user's performance viewed in opposition to the inauthenticity of the nonnative language learner. Characteristic of a romantic view of authentic speech is that it is "native, spoken, verbatim, unrehearsed, off-the-record, sincere, vernacular and non-standard" (p. 41). If a corollary of the legitimization of authentic language is the delegitimization of some other kinds of language as inauthentic, crucial questions include: Who has authority to make this distinction, and who validates authenticity claims? Bucholtz (2003) proposes the concept of authentication as an alternative to authenticity. Whereas authenticity presupposes that identity is primordial, authentication views it as the outcome of constantly negotiated social practices. It is the tactic of authentication that produces authenticity as its effect. We should therefore attend to the authenticity effects achieved through the authenticating practices of those who use and evaluate language. This perspective views authenticity as a process rather than as a fixed state. Gill (2011) argues that rather than asking what is authentic, we should ask what it means to be authentic in a particular setting, according to what norms, and what are the authenticating practices by which it is conferred or denied. We should pay attention to how speakers use the notion of authenticity, to what ideological ends, through which authenticating practices. In this article we will consider the authenticating practices of students and teachers as they use and evaluate linguistic resources in their classroom.

Kramsch (1998) points out that native speakership brings to its speakers a certain authority associated with authenticity and legitimacy of language use. Native speakers are often viewed as the genuine article, the authentic embodiment of the standard language. Gill (2012) points out that "the figure of the native speaker has long been instrumental in defining the apparently commonsense linguistic boundaries of authentic belonging, in relation to which the non-native speaker has been positioned" (p. 273). In second language learning, the notion of the authenticity of the native speaker and of the language used by the native speaker has been one of the cornerstones of communicative language teaching. To claim or assign authentic or legitimate native speaker 
status may also be to claim or assign other statuses, including ethnic, moral, and educational (Doerr \& Kumagai, 2009). However, in language teaching as elsewhere, linguistic signs cannot work alone in the business of claiming authentic membership. Rather, it is the interplay of linguistic features with other emblematic features that allows an individual to claim, or to be assigned, authenticity. And it is the interplay of social, political, and historical contexts with all of these features that affords or constrains the legitimacy of such claims and assignations. Coupland (2003) argues that the notion of romanticised authenticity has been superseded by a conception of authenticity in which meanings are locally negotiated in reflexive and strategic communicative practice. That is, in late modernity, we have to work with more nuanced assumptions about the authentic speaker, and look at authenticity in performance. There is a need for a more complex, situated understanding of distinctions among native speakers, and between native and nonnative speakers (Doerr \& Kumagai, 2009).

Kramsch (2012) makes a distinction between authenticity and legitimacy, proposing that they are related concepts, but of different value, "one entails the other, as a legitimate speaker is assumed to be an authentic member of a group" (p. 490). Van Leeuwen (2007) proposes that legitimation is always the legitimation of the practices of specific institutional orders. Kramsch also argues that legitimacy requires the sanction of an institution, but adds that authenticity requires a link to an identifiable origin that confers a natural and therefore unquestioned authority. At the same time she questions whether, in a world where mobility and global flows are slowly erasing cultural and national origins and multiplying the centres of authority, it makes sense to talk about authentic native speakers and teaching materials, and to refer to legitimate forms of speech. Kramsch introduces the notion of imposture, which can index a person's inability to occupy the slot legitimately meant for them. Individuals may be positioned as authentic speakers of a language despite their own doubts about their legitimacy to perform the role assigned to them-that is, they may feel that they are imposters in the role. Martin-Jones and Heller (1996a) argue that legitimacy can best be understood in the context of relations of power among the speakers in question, both inside and outside the classroom. They also demonstrate that legitimate knowledge and legitimate language in education can be contested in a number of ways, and in a number of sites (Martin-Jones \&
Heller, 1996b). In these processes, the positioning of the individual is not always negotiable (Blackledge \& Pavlenko, 2001). For example, in schools in the United Kingdom and elsewhere, teaching staff who look like legitimate speakers of certain languages are frequently imposed upon as ad hoc interpreters in interactions with students and their parents. Or the same teaching staff is imposed upon by their well-meaning colleagues to translate letters, notices, and displays into languages and scripts in which they claim no expertise. Instead of being experts, they become imposters, required in spite of themselves to behave as if they were legitimate experts.

Heller (1996) draws on Bourdieu (1977) to propose that the key elements of legitimate language (or discourse) include being a legitimate speaker and addressing legitimate interlocutors, under specific social conditions, in language that respects specific conventions of form. Heller extends Bourdieu's notion of form to consider how examining language in use reveals the relationship among the different dimensions of legitimate language. Heller clearly demonstrates that certain language practices and language forms are considered legitimate in educational settings, whereas others are not, and suggests that "our job is to understand why some language is legitimate and some is not and what that means for the participants in the setting” (p. 141). Kubota (2009) points out that some of those who do not fit the image of a legitimate speaker of a language are in fact native speakers of the language. Conversely, some of those who fit the image of a legitimate speaker are nonnative speakers of the language. Thus the legitimacy of the native speaker is not based purely on the linguistic attributes of individual speakers, as language proficiency interacts with other social, cultural, and political features, such that "native speakerness does not always guarantee a position of power in certain educational settings" (p. 241). Kramsch (1998) proposes that we view the notions of authenticity and legitimacy from a poststructuralist perspective, in which the certain divides between authentic and inauthentic, and legitimate and illegitimate, may no longer hold. Kramsch argues that poststructuralist applied linguistics "can help multilingual subjects interrogate the larger flows of people, knowledge, and capital and their own vulnerability in playing the paradoxical roles that are required of them" (p. 499).

In the study reported in this article, teachers and students negotiate legitimacy and authenticity through the deployment of nuanced linguistic 
signs and through evaluation of distinctions between them. In the classroom, individuals are positioned-and position themselves-in terms of a range of possible native speakerisms, and these positionings have social consequences. Linguistic and other semiotic signs serve as benchmarks of authenticity and legitimacy, as teachers activate (or fail to activate) the right kinds of social and cultural capital to legitimise and authenticate their standing in the classroom.

\section{A PANJABI COMPLEMENTARY SCHOOL IN BIRMINGHAM, UK}

The study reported here is part of a 32-month project funded by the European Science Foundation/Humanities in the European Research Area. The project aimed to investigate the range of language and literacy practices of multilingual young people in four European cities, to explore the cultural and social significance of these practices, and to investigate how their language and literacy practices are used to negotiate inheritance and identities. The focus of the present article is linguistic ethnographic research conducted in a Panjabi complementary (also known as community language, heritage language, or supplementary) school in Birmingham, UK. Over the last 12 years, Blackledge and Creese have been researching language and literacy practices in complementary schools. We have investigated the communication practices of young people and teachers in Bengali, Chinese, Gujarati, Panjabi, and Turkish language classrooms, during their break times and, in some cases, in their homes (Blackledge \& Creese, 2010).

Many thousands of young people in the United Kingdom attend complementary schools for several hours each week. Complementary schools serve specific linguistic or religious and cultural communities, particularly through community language classes. Largely outside of the state's apparatus of control and regulation, they provide an autonomous space for alternative educational, linguistic, social, and cultural agendas (Blackledge \& Creese, 2010; Francis, Archer, \& Mau, 2008; Martin et al., 2004; Mirza \& Reay, 2000).

The Panjabi school in which we conducted our observations operates on Saturdays, and is additional to mainstream schooling. The principal told us that it was set up "to provide more quality teaching in Panjabi than was being offered in Birmingham at the time." The school was established in 2004 by a group of successful Birmingham businessmen. One of the sites is a building owned by the school, while the second borrows the classrooms of a local mainstream secondary school. Across the two sites there are approximately 15 teachers and teaching assistants teaching 200 pupils, ranging from 5 to 18 years. The teachers do not have official teaching qualifications, but do have a qualification in Panjabi. The teaching assistants are typically college and university students. Those involved speak of a school that has the same rules and procedures as a mainstream school. The principal speaks of "excellence, high enrolment, over-subscription, waiting lists, word-of-mouth successful recruitment, organized teaching and administrative procedures."

The authors spent one academic year observing in all classes in the school every Saturday and writing detailed field notes. Each week, the researchers exchanged field notes and discussed their observations in the field. After an initial 5 months of observation during 2010 and 2011 across all classes in the school, one class in each site was identified for closer observation. Both classes were multi-age, with students from 10 to 18 years. In negotiation with the teachers of these classes, two students in each class were identified as key participants for focused observation. After further observations in these two classrooms, the identified students, teachers, and teaching assistants were issued digital voice recorders so that they could audio record their linguistic interactions during class time. The participants were also asked to keep the recorders during the week between Panjabi school sessions, to record themselves at home and in other environments. The researchers continued to observe in the classroom every Saturday throughout the academic year. They also interviewed 15 key stakeholders in the schools, including teachers and administrators, and students and their parents. Takhi conducted a majority of the interviews either bilingually or monolingually in English and/or Panjabi; Takhi also transcribed and translated all audio recordings including classroom, break time, and home interactional recordings throughout the research project.

The linguistic ethnographic approach we adopted is an interpretive approach that studies the local and immediate actions of actors from their point of view and considers how these interactions are embedded in wider social contexts and structures (Creese, 2008, 2010; Maybin \& Tusting, 2011; Rampton, 2007; Tusting \& Maybin, 2007). It is a "disciplined way of looking, asking, recording, reflecting, comparing, and reporting" (Hymes, 1980, p. 105), combining discourse analysis with ethnography. We collected 
TABLE 1

Participant Information

\begin{tabular}{|c|c|c|c|c|}
\hline $\begin{array}{l}\text { Name of } \\
\text { Key Participant }\end{array}$ & $\begin{array}{l}\text { Role in Panjabi } \\
\text { Complementary } \\
\text { School }\end{array}$ & Age & Place of Birth & Outside Employment \\
\hline Hema & Senior teacher & 42 & $\begin{array}{l}\text { Panjab, India; moved } \\
\text { to UK } 16 \text { years ago for } \\
\text { marriage }\end{array}$ & $\begin{array}{l}\text { Sixteen years as a teaching } \\
\text { assistant at mainstream } \\
\text { secondary school }\end{array}$ \\
\hline Narinder & Teaching assistant & 27 & $\begin{array}{l}\text { Panjab, India; moved } \\
\text { to UK one year ago for } \\
\text { marriage }\end{array}$ & $\begin{array}{l}\text { Recently employed as teach- } \\
\text { ing assistant at mainstream } \\
\text { secondary school }\end{array}$ \\
\hline
\end{tabular}

four kinds of data: observational field notes; audio recordings of interactions between participants; semi-structured interviews; and field documents, including teaching materials and photographs. Over the course of a year in the Panjabi complementary school we made 42 observations of classrooms, with each visit producing extensive field notes, redrafted four times for their analytical value. We collected 104 audio recordings from our research participants and conducted 15 interviews. In selecting data for this article, we used our field note observations which recorded, over time, the young people's behaviour toward their two teachers. We then used our field notes to link to relevant audio recordings from the corresponding date. The three authors then listened to the recordings together before deciding whether the audio should be transcribed and, if necessary, translated. We typically come to our interview data after we have interrogated these other data sets. As ethnographers we are aware of our age, family history, ethnicity, and bilingualism opening up and closing down relations in the field. We are also aware how our social experiences shape both our analysis of the data, and the knowledge we produce. We actively work at a reflexive approach to document these constructions (Blackledge \& Creese, 2010; Copland \& Creese, 2015; Creese \& Blackledge, 2012).

In this article we discuss the Saturday class housed in the secondary school, and focus on two adults: the regular class teacher Hema, ${ }^{2}$ and her teaching assistant Narinder. From Monday to Friday, both Hema and Narinder worked together as classroom assistants in the same mainstream secondary school which the complementary school borrowed for its Saturday classes. Hema had worked for the past 16 years in this mainstream school, whereas Narinder had been employed there for 6 months. Narinder had lived in the United Kingdom for 1 year at the time we were observing in the school. The data represented in this article consist of field notes, classroom recordings, and interviews.
Both Hema and Narinder came to the United Kingdom for marriage. Narinder had a master's degree in Mathematics Education, which she obtained in India. Hema had a master's degree in Economics, also obtained in India, and a qualification for teaching adults, which she achieved in Birmingham. Both describe themselves as multilingual, and between them mention proficiency in English, Hindi, and Panjabi. Hema and Narinder share a similar concern that their English pronunciation sets them apart from perceived native speakers of English. ${ }^{3}$ When we interviewed her, Narinder said:

Here I can't understand the accent. But like you say "are you all right?" I could never understand what they were saying. ... in India we say everything letter clearly. It's the style of speaking here though. It took me three or four months to get used to this line. Now I've learnt that I'm OK with it all. These few words"hello," "hi," my brain struggled a bit at first about when to use these words. Now I've learned those and my speaking is OK.

In her interview, Hema looked back over her 16 years in the United Kingdom and commented:

When I was first here I was in a bit of difficulty because our English, to us the pronunciation here and over there was very different.

Both Hema and Narinder described attempts to keep their languages separate at home. However, Hema also described mixing as common practice:

Both languages, yeah both languages, we mix them, yes, when they don't understand and we don't have words in Panjabi to describe to them, we then describe them in English.

Narinder described her efforts to keep her languages separate, as she sought to preserve her Panjabi by keeping domains of use apart: 
"When I came here I told my family straight up that I want to speak Panjabi within the family, and English is my work language. This is the routine I want to keep." She also commented:

Now I am worried that I will forget Panjabi . . . I am still trying to stay within my own language as much as possible. But I am seeing that English is becoming the norm for so many people. There is the fear that in a few years we don't know where our language is going to be.

Both Hema and Narinder were passionate about preserving the Panjabi language, and about the importance of the language to their lives and identities. Hema noted:

I think our language is extremely important . . if you don't know your language then what will you do? And secondly if you have your roots, if a tree doesn't have roots then how big will that tree grow? You won't have any self-confidence, because you won't know who you are. Without an identity then what will you do?

A range of ideologies is in play in these narratives. Narinder makes a distinction between the clarity of pronunciation of English in India and the unfamiliar regional dialect of the Midlands of England. Hema also distinguishes between "pronunciation here and over there," a distinction which caused her some difficulty when she arrived from India. The two women articulate slightly different positions in relation to the maintenance of the Panjabi language in the diasporic setting. Narinder is anxious that the language will disappear as English becomes the norm for many people of Panjabi heritage. Hema has a more positive orientation to maintenance of the heritage language, citing an indexical link between knowledge of the language and the "roots" of identity and self-confidence. At the same time, Hema is confident that mixing languages is a legitimate and everyday practice which arises from pragmatic communicative need. Narinder, however, has a strategy of keeping her languages separate, with Panjabi linked to home life, and English reserved for the domain of work. These ideological orientations to language proficiency and use are in play as we turn our focus to linguistic practices in the classroom.

\section{NEGOTIATING AUTHENTICITY IN THE LANGUAGE CLASSROOM}

A feature of Hema's classroom pedagogy is her insistence on the correct production of particular features of Panjabi. These include, among others, subject-verb agreement, pragmatically appropriate greetings, and pronunciation. Students are asked to recite particular sounds repeatedly, and to look for distinctions between sounds. Field notes written during classroom observations record a typical instruction from the teacher: Hema tells the students off (gently) for not distinguishing between sounds. "Look at me. Take your tongue to the top. OK, now say this five times. Come on, all together."

Hema insists on correct pronunciation of Standard Panjabi. She represents herself as a model of good pronunciation, while also referring to other authentic sources available to students: "Come on, pronunciation. Just think how your bibi < grandmother $>$ would say it." Hema constructs the grandmother, and in fact the grandmother generation, as an authentic model of correct pronunciation of Panjabi.

In an audio recorded interaction, Example 1, Hema positions the newly arrived classroom assistant, Narinder, as another authentic model of pronunciation. In this example, Hema is conducting a dictation exercise, in which the students are required to write the Panjabi text spoken by the teacher. We pick up the recording at the point where Hema asks Narinder to act as a model of good pronunciation (Kirsty is a 14-year-old student): ${ }^{4}$

\section{EXAMPLE 1}

Hema [aside to Narinder:] do you want to do this?

Narinder kithayak? <whereabouts?>

Hema yeah stress dekay word, bolnay OK? $<$ yeah stress the word, with emphasis $O K$ ? > [whispers:] saaday <our $>$

Narinder [to students:] saaday ghar $<$ our house $>$ de vich $<$ in it $>$

Hema [to Narinder:] yeah "saaDay" so they, they hear the sound

Narinder OK [reads slowly:] saaDay ghar <our house $>$ de $<o f>$ laagay $<$ near $>$ ek $<a>$ vaddi sarakh hai $<$ is a big road $>$

Hema [to students:] OK listen to me OK, when somebody's talking you, you look people's lips like how they're pronouncing this, OK. Miss said "saaDay" < our $>$. When you pronounce this " $\mathrm{d}$ " where are you are taking your tongue? Where I'm taking my tongue? "sAAday," so which dadda $<d$ sound $>$ you need? All of you got dadda wrong- -saaDay."

Narinder [to Hema] repeat kardaa? < shall I repeat it?>

Hema sAADay

Narinder sAADay ghar de laagay ek vadi sarakh hai <near our house there is a big road> 
Hema OK when I'm saying "saaDay" my tongue is going the top, yeah? So which dadda I need to put, you need to write saaDHay or saaDay?

Kirsty saaDay

Hema so which dadda you need?

Kirsty is it that one?

Hema it's like a three with a loop, that's why I told Miss to do this, so you can see the difference how she's pronouncing it and how you are writing

Hema teaches the students the distinction between different / $d$ / (dadda) sounds in Panjabi. Her teaching point is about the distinction between the phoneme /d/ with and without aspiration. She contrasts "saaDHay" and "saaDay" to make a point about similar words with different meanings: "SaaDay," meaning "our," and "SaaDHay," "half past" [the hour]. Hema makes her teaching point by constructing both Narinder and herself as authentic native speakers who are able to model the distinction between the aspirated and unaspirated sounds. However, she appears to construct them as different kinds of authentic speakers of Panjabi. Hema asks Narinder, relatively recently arrived from India, to stress and emphasise key sounds so that the students can clearly hear them. In doing so, she invokes Narinder as the authentic model of Standard Panjabi pronunciation. Hema positions "Miss" as the authority in making distinctions between sounds in Panjabi. She asked Narinder to act as a model of good pronunciation so the students "can see the difference how she's pronouncing it and how you are writing." In this interaction Hema's positioning of Narinder as the newly arrived, authentic native speaker is intended to remind the students of a Standard Panjabi that is linked to the Panjab. It is not clear that Narinder has been consulted about this before the class began. Field notes suggest that Hema is attempting to be inclusive here, providing Narinder with a role as a teacher. Hema draws on Narinder as an available resource, but her positioning of the junior teacher as a native speaker and authentic model of Panjabi pronunciation may not be negotiable.

It is notable in this interaction that Hema refers not only to the sound but to the embodiment of correct, or standard, pronunciation. She instructs the students to watch the shape and movement of Narinder's and her own mouth as each of them pronounces the /d/ and /dh/ sounds: "Take your tongue to the top," "you look people's lips," "where I'm taking my tongue?," "my tongue is going the top, yeah?" Hema positions both
Narinder and herself as teachers who not only sound authentic, but who embody authentic pronunciation, moving their tongue and lips in an authentic way. That is, their historical body (Scollon \& Scollon, 2004) or their bodily hexis (Bourdieu, 2008) is assumed to equip them with the cultural capital to produce authentic pronunciation of Panjabi. This authenticity appears to be linked to their status as native speakers, and to the students' (perceived) status as nonnative speakers. Hema tells the students that because they failed to watch the way she and Narinder move their lips and tongues, they made mistakes in their written dictation: "all of you got dadda wrong."

However, while Hema positions Narinder as the authentic speaker, Narinder herself appears to be less convinced of her legitimacy as a teacher. Her Panjabi dictation is hesitant at first, and Hema immediately interrupts Narinder to model "saaDay," and to instruct her, "so they hear the sound." Hema is initially dissatisfied with Narinder's production of the sound that will be the focus of her teaching point. Notwithstanding the fact that Hema has put Narinder in the position of the authentic native speaker of Panjabi, she quickly corrects her, and offers a more legitimate version of "saaDay" as a model for Narinder as much as for the students. Hema positions Narinder as authentic but simultaneously, and paradoxically, as illegitimate (Kramsch, 2012). Narinder does not lose her status as an authentic speaker of Panjabi, but as a result of being put in the spotlight her legitimacy as a teacher comes under scrutiny and is called into question, not least by herself. Kramsch (2012) argues that an individual's feelings of uncertainty about whether they are authorised to speak may lead to feelings of "imposture" (p. 485). Here Narinder is required to speak, but is at first hesitant, then after being interrupted by Hema seeks permission to resume: "repeat kardaa?" Rather than simply agree that Narinder should repeat the sentence for the students, Hema once again prompts her by modelling the relevant sound for her colleague: "sAADay." While she positions Narinder as an authentic native speaker, Hema is sharply aware that her colleague may need support in order to become a legitimate teacher.

\section{NEGOTIATING LEGITIMACY IN THE LANGUAGE CLASSROOM}

Questions of authenticity and legitimacy also relate to the pronunciation of English in this classroom, as differences in pronunciation serve 
to index the teaching assistant's status as newly arrived from the Panjab. Creese's field notes record the following observation:

A child asks Narinder for clarification about her translation from Panjabi to English. He wants to know if she said "eating." She repeats and says "knitting," but with a very long /i/ sound. The young man still looks a bit perplexed and so Narinder writes the word on the board. She writes "kneeting." This causes the class to snigger.

The distinction between the English phonemes /i/ and / 1 / is problematic for Narinder, and results in the incorrect written representation of the word "knit" as "kneet." Her position as the authentic native speaker best able to represent different /d/ sounds in Panjabi has been supplanted here, as she becomes the nonnative speaker who is unable to distinguish different /i/ sounds in English. The students impose their own benchmarks of authenticity and legitimacy, and the students' sniggers indicate that at this moment Narinder has not met them. Narinder's illegitimacy as a teacher does not necessarily reside in the students' expectation that she should be able to produce correct Standard English. As we have seen, Hema often spoke to the students in a nonstandard variety of English: "when somebody's talking you," "you look people's lips," "where I'm taking my tongue?" and so on. The students are familiar with Hema's nonstandard variety, which may be described as Birmingham Asian Vernacular English. The dialect is recognizable to the students, even if they tend to use a more Standard variety of English themselves. In the eyes of the students, the distinction between Hema's nonstandard speech and Narinder's confusion with the sound and spelling of the word "knitting" is that while Hema's Birmingham Asian Vernacular English is familiar, and so indexes the local, Narinder's attempt at Standard English pronunciation and spelling indexes an identity as newly arrived and fresh. Talmy (2004) refers to the discursive construction of the newly arrived, "fresh-off-the-boat" student, relationally defined against an unmarked, idealized native speaker. (Blackledge \& Creese [2010], Creese et al. [2006], and Martin et al. [2004] discuss the notion of freshie subject positioning in complementary schools in the United Kingdom). Talmy refers to linguicism at work in the social practice of "the public teasing and humbling of lower L2 English proficient students by their more proficient classmates," which "was one of the primary ways that students produced and reproduced the linguicist hierarchy" (p. 164). In the case reported here, students humble not each other, but the assistant teacher. The distinctions are nuanced and relatively subtle, but immediately recognizable to the students. The legitimacy of the teacher at least partly depends on the production of speech and writing that the students recognize as authentic. Kubota (2009) and Kramsch (2012) counsel that other semiotic features than the linguistic come into play in the negotiation, imposition, or withdrawal of authenticity and legitimacy. Features of Narinder's appearance and behavior contributed to the students' response to her as a teacher. But the linguistic was clearly one dimension of the configurations of emblematic features that served as benchmarks of legitimacy.

Gee (1999) describes how relatively small differences function as large and important ones with social consequences. The examples of phoneme production in these multilingual classroom practices are what Silverstein (1976) refers to as "nonreferential" or "pure" indexes (p. 39). They are "features of speech which, independent of any referential speech events that may be occurring, signal some particular value of one or more contextual variables" (Silverstein, 1976, p. 29). Some signs are heavy on indexical value and light on referential value. For example, phonological and intonation features of language can send signals about speakers without referring to a specific referent or object. They position the speaker socially and limit the space to negotiate alternatives (Pavlenko \& Blackledge, 2004). As we have seen, the young people in the Panjabi class make much of small vowel differences in English to position Narinder as different from themselves. Narinder's arrival in the class attracted comment from students and researchers:

I feel nervous for Narinder-it's not clear what she wants from the children as they start the whole class feedback event. At one point I hear a child answer in Panjabi to a housekeeping conversation. This is unusual and Narinder's native Panjabi seems to mean that there is more Panjabi spoken in class. However, it also brings more comments from the students and more laughter and general undermining. She speaks again in Panjabi and this time one of the older boys shouts “¿qué?” in Spanish, and there is laughter. (field notes)

Here, a novice teacher is finding her feet, and at this stage is out of alignment with the normative 
practices of this classroom. Housekeeping and classroom management is usually conducted in English, whereas Narinder addresses the students in Panjabi. First, the researcher reports feeling nervous for the new adult put in charge. This worry is not recorded in observations of other teachers. Second, as the deployment of Panjabi in the classroom increases, the linguistic ecology changes. Third, this change in language use is marked by a change in student behaviour, which becomes more disruptive than usual. The student's shouted “¿qué?" positions Narinder as an outsider, and leads to student laughter. The invocation of “¿qué?" imposes a foreign rather than a community language teacher identity. It may be that the stylised “¿qué?" references Manuel, a character in the popular BBC television comedy, Fawlty Towers. Manuel is a wellmeaning but disorganised and constantly confused waiter from Barcelona, a "freshie" with a limited grasp of English language and customs. The students appropriate this stereotype as a resource with which to contest Narinder's legitimacy as a teacher. Once again this is based on nuanced distinctions, as Narinder (probably unwittingly) transgresses the norms of the classroom. Too much Panjabi and not enough English from the new teacher means that the students position her as illegitimate in their classroom.

Another example recorded in a brief field note records Creese's observation of Narinder's approach to classroom management and discipline:

Narinder tells a boy off in Panjabi about chewing gum and tells him to spit it out. He answers her question in Panjabi, and this causes the class to laugh. Narinder doesn't seem to understand about the relaxed environment.

Narinder's insistence that students don't chew gum or use their mobile phones sets her apart from the other teachers in the school, where restrictions on mobile phones are usually relaxed, children eat food in the classroom, listen to music on their mp3 players, log into Facebook, connect to email, and use the internet. Narinder's less permissive regime disrupts the usual classroom norms. The class laughs at the student's response in Panjabi because it is nonnormative, serving as a metalinguistic comment, a verbal representation that mimics the teacher and in doing so indexes Narinder as newly arrived. In the examples here, the stylised representation and mimicry of Narinder's voice appears to point to the students' evaluation of her as fresh off the boat. Narinder's insistence on Panjabi as the language of classroom management may be authentic, but (together with her transgression of other classroom norms) it undermines her legitimacy, as the students put in place their own benchmarks of what counts as legitimate.

In audio recorded Example 2, Hema has to leave class early, and is about to hand over responsibility for the students to her assistant, Narinder:

\section{EXAMPLE 2}

Narinder [to Hema in an aside:] Miss tell them ke class'ch noise na karn sochde ke new teacher aa hana? < miss tell them not to make any noise in the class they think it's a new teacher right?>

Hema kaun kehndaa aa idhaa? < who says that?>

[to students:] I'm going now. Miss will mark your work and she will go through the sentences with you, OK? Since I have take charge of this [other] class I am trusting you lot, OK? It's my trust that you are the excellent students, OK? And no matter if I leave my lesson class here, if I go next lesson next door you will behave, OK? But now I'm leaving two adults here, OK? The respect you give me I want the same way you give respect to these two teachers, OK? OK and next week if I hear any complaint from Miss somebody misbehaved or they were chatty, OK, then I will have a word with your parents. That's serious then, OK? If you can respect me, the same way you should respect Miss as well OK? Is that OK? Put your hand up if you can't behave. OK.

Narinder yeah please. now [laughs:] tell me now

Hema [to Narinder:] OK Miss now all is Narinder OK yours. Now this is your class now

In the first utterance here, Narinder represents her anxiety about taking over responsibility for the class of students in Hema's absence. She moves flexibly between English and Panjabi, including deployment of a word, "class'ch," which incorporates signs from both languages ("class'ch" is an elision of "class de vich," meaning "in the class'). However, Narinder's translanguaging is perhaps of less interest than her anxiety about her 
legitimacy as a teacher (Creese \& Blackledge, 2010). Hema seeks to reassure her ("kaun kehndaa aa idhaa?" < who says that? >), and turns to the students to lecture them about their response to the new teacher ("two adults" here refers to Narinder and the researcher, Creese). She begins by complimenting them, saying she trusts that they are excellent students. She goes on to insist (four times) that they must respect Narinder. She threatens them with their parents if there are any complaints. When Hema finishes her brief lecture, Narinder makes a joke and laughs nervously, which appears to betray her feelings of imposture (Kramsch, 2012) and to point to her doubts about her legitimacy to perform the role assigned to her. Finally Hema hands over the class in a relatively formal, almost ritualistic exchange. Although we have seen that Hema positioned Narinder as an authentic model of good Panjabi, this is not sufficient to overcome Narinder's own doubts about her legitimacy as a teacher. She is far from certain that she has achieved the status of the legitimate teacher in the eyes of the students. In taking over the class from Hema she feels like an imposter, her positioning as an authentic speaker at odds with her doubts about her legitimacy as a teacher.

\section{CONCLUSION}

Kubota (2009) calls for the problematization of the native speaker as the ideal teacher, and for scrutiny of the complex power dynamics behind who is positioned as an ideal teacher, in which contexts, to serve whose interests. She proposes a perspective that recognises the intersection of multiple contexts and social categories in investigations of the authenticity and legitimacy of the native speaker and nonnative speaker teacher. Such a perspective explores how the interplay of different factors, such as competing discourses and a specific social space as a site of struggle, influences the activation of capital as a form of power related to native speakerness. Doerr (2009) suggests shifting our analytical focus to examine the ways in which language ideologies affect daily practices and perceptions of people through language policies, schooling practices, and discursive practices. In the examples presented in this article multiple contexts, ideologies, and power relations are in play, and are identifiable in the warp and weft of classroom interaction.

The authenticity and legitimacy of the native speaker is an ideological construct discredited in scholarly research but apparently credible to the students and teachers in this study. By paying attention to the ideologies at work in the classroom, and the indexical orders that constitute them, we can gain understandings of the nuanced negotiations through which the language teacher may assume, or may be ascribed, alignments that include (versions of) authentic, inauthentic, legitimate, illegitimate, fresh, and imposter identity positions. Analysis that addresses orders of indexicality pays attention to the sign as an index of other social phenomena and contexts. In this Panjabi classroom, the deployment of linguistic signs links to social characteristics through local language ideologies. Emblematic templates and indexical orders serve as concepts for explaining how local practice is related to wider structures (Silverstein, 2003). Over the course of a year observing in this classroom we saw that a range of language ideologies coexisted in dynamic equilibrium. One set of ideologies held that correct pronunciation of Panjabi should be practised in order to produce more accurate written text. The pedagogic aim of teaching correct pronunciation further endorses and upholds the Standard variety. In our field notes and interviews participants commented regularly on varieties of Panjabi. For example, varieties include "posh," "rough," regional varieties, "Pakistani Panjabi," "African Panjabi," "English Panjabi," and "decent Panjabi." The principal mentioned that Panjabi families at the school pass on a "rough" variety of Panjabi: "Over time I've found that some of the families here whose ancestors I would say or grandparents came from really rural backgrounds-from villages. They passed on the language, very rough, very-not very posh language to their next generation and next generation passed it onto the young children." He describes this variety as "not very respectful," and "not very nice Panjabi," and says that he has to stop the children at the school from speaking in this way. He makes a further distinction between the Panjabi spoken by people born and raised in the Panjab and the Panjabi spoken by people born in the diaspora, saying "whoever is born over here they speak actually Panjabi in an English accent." A pedagogic rationale of the school appeared to be to counter the spread of nonstandard varieties.

Allied to this was the construction of the newly arrived native speaker of Panjabi as an authentic model of good pronunciation. Narinder's newly arrived status was associated with a pure model of the Panjabi language. She was positioned by the senior teacher as the very embodiment of the authentic Panjabi speaker. Another ideological position, held by savvy, teenage students, was that the legitimacy of the newly arrived teacher was 
undermined when she was not able to produce (emblems of) an authentic variety of English. A novice in the classroom, and lacking confidence in her ability to meet the students' criteria for teacher legitimacy, she felt like an imposter in front of the class. These ideologies coexisted in dynamic equilibrium in this classroom, and were negotiated and imposed from moment to moment.

Evaluation against benchmarks of authenticity and legitimacy included attention to certain semiotic signs: the production of the aspirated and nonaspirated / d/ phoneme in Panjabi; the movement of the lips and tongue in particular ways; recognisable pronunciation and spelling of English words; the nonnormative deployment of Panjabi for classroom management. Native speaker positioning underwent constant construction, regulation, and surveillance. Teachers, assistants, and young people were involved in an ongoing process of evaluating, aligning with, and distancing themselves from particular identity positions, in the "perpetual semiotic reorientations of identity work" (Blommaert, 2012, p. 6). Blommaert and Varis (2011) point out that discourses in which people identify themselves and others include "a bewildering range of objects towards which people express affinity, attachment, belonging; or rejection, disgust, disapproval" (p. 4). In adopting an ideological lens to examine the language classroom it is demonstrable that native speakers are far from homogeneous, and that ideological orientations to native speakerness are changeable and dynamic.

In many countries, government discourse links teaching quality to improved educational standards. Policy statements speak of teacher professional development that is "relevant, useful and focused" on raising student achievement (No Child Left Behind, 2004, p. 5-henceforth NCLB) and which makes use of research based on "rigorous, systematic and objective procedures to obtain reliable and valid knowledge relevant to education activities and programs" (NCLB, 2004, p. 30). The linguistic ethnographic approach we have taken in this research meets these criteria, and in this final section we contemplate what the study can contribute to teacher development, professional knowledge, and classroom practice. In this regard, we make several points linked explicitly to NCLB's categories for high quality professional development.

\section{Subject Knowledge and Language Proficiency}

Improving a teacher's subject or content knowledge is a fundamental criterion of high quality professional development. For the language teacher, proficiency in the taught language is a professional given. Subject knowledge in language teaching assumes clear benchmarks of linguistic and cultural proficiency. Our study shows that proficiency is not fixed, but rather depends on local knowledge about student lives and community histories. Linguistic prowess and skill is much more than the use of an unchanging linguistic standard in a target language linked to a country of origin. Rather, an ability to draw on a range of linguistic resources which index a similarly complex range of social and historical experiences is an important proficiency for the language teacher in the language classroom. Migration histories, local Birmingham knowledge, and shared aspirations around education and employment all play into the teacher-student relationship and are indexed through the use of the most minute of linguistic signs. We argue that teacher professional development must work with a comprehensive view of the language teacher that attends to the social context, power relations, and ideologies in play and not to static notions of native-like proficiency. Like that of Kubota (2009), our research shows that "native speakerness does not always guarantee a position of power in certain educational settings" (p. 241); differences in Narinder's and Hema's legitimacy as teachers of Panjabi are not predicated on their expertise in Panjabi but rather emerge in relation to English language attributes that interact with other social, cultural, and political features.

\section{Improving Classroom Management Skills}

Our study has shown that teacher authority is linked to issues of authenticity and legitimacy. Narinder is a novice teacher who has lived in Birmingham for less than a year, while Hema has many more years of teaching experience in different contexts in the city. We have argued that authenticity is a dynamic process that can no longer be viewed as fixed, or as a romantic notion of heritage that can be straightforwardly transmitted. Authenticity is locally negotiated, and strategically communicated in the back and forth of classroom power relations between students and teachers. In this study, students imposed their own benchmarks of authenticity, which required the teacher to deploy an English vernacular that was recognisable to them. In this classroom, students endorsed one construction of bilingualism rather than another. Hema's combination of a local English vernacular with the standard Panjabi variety was for the students a more 
credible construction of bilingualism. Hema's language use indexed students' local lives in ways that Narinder's language use was unable to. This left Narinder vulnerable. She was unable to put her repertoire to use to the same social effect as Hema, and this caused classroom management problems. In turn, the linguistic repertoire she had access to meant further changes in the linguistic and social ecology of the classroom. Her overall strictness and use of the target language worked against her in a classroom context that was outside the normal regimes of statutory education. These changes led to minor disruption and classroom management issues, as the students reacted to changes in normative patterns and gave her a hard time. Narinder was aware of this and looked for help from Hema. Discussion of what measures might have been taken to develop Narinder's skills in managing the class requires more than a simple toolkit response. Indeed on the face of it, Narinder was already implementing classroom management skills that should have led to authority and control. Rather, we are concerned with the ideological nature of language teaching that is deeply politicised and hierarchized. Narinder was constructed by students learning Panjabi as a freshie despite Hema's best efforts to present her as a highly skilled, expert native speaker. Narinder's journey into becoming a legitimate teacher was a painful one, and learning from these events would require individual reflexivity, improved in-classroom teaching partnerships, and an increased student awareness of linguicism.

Adapting Heller (1996), we suggest that legitimacy in the Panjabi classroom is about knowing when and how to deploy certain linguistic resources, and about being a member of a group with the right to use them, or not to use them, depending on the circumstances. Based on our analysis of classroom interaction over the course of a year, we argue for an ideological orientation to language teaching which recognises the diversity and variability of experience as the norm, and views excellence as locally negotiated. In linguistically diverse Birmingham, we found the legitimate Panjabi native speaker was not the teacher who separated two different languages, and linked these to the standard varieties of particular regions. Rather we found a highly valued teacher whose normative mode was a nonstandard variety of Midlands English, who had the ability to translanguage, was able to draw on linguistic and community repertoires, and use local knowledge to engage students. However, the success of Hema as a bilingual teacher skilfully deploying her linguistic resources is balanced against the students' construction of her colleague as a freshie. Sets of beliefs about the production and deployment of certain linguistic signs were powerfully in play in this language learning classroom, as teachers and students negotiated what counts as the authenticity and legitimacy of the native speaker teacher. An analytical lens which focuses on the ways in which local practices constitute, and are related to, orders of indexicality and language ideologies offers an understanding of complex, situated, and nuanced negotiations of power in claiming and assigning authenticity and legitimacy in language learning contexts.

\section{NOTES}

${ }^{1}$ In England, General Certificate of Secondary Education (GCSE) are examinations taken by school children at age 16 years.

${ }^{2}$ All participants' names have been changed to ensure anonymity.

${ }^{3}$ Hema and Narinder used both English and Panjabi in their interviews. In the examples quoted here the translation into English was done by author Jaspreet Kaur Takhi.

${ }^{4}$ Transcription conventions are used as follows:
(.)

speech

$<$ speech >

CAPITALS

(XXX)

[ ] pause of less than a second length of pause in seconds transcribed speech translated speech loud speech inaudible 'stage directions'

\section{REFERENCES}

Blackledge, A., \& Creese, A. (2010). Multilingualism: A critical perspective. London: Continuum.

Blackledge, A., \& Pavlenko, A. (2001). Negotiation of identities in multilingual contexts. International Journal of Bilingualism, 5, 243-259.

Blommaert, J. (2012). Complexity, accent and conviviality: Concluding comments. Tilburg Papers in Culture Studies, 26. Tilburg, the Netherlands: Tilburg University.

Blommaert, J., \& Varis, P. (2011). Enough is enough: The heuristics of authenticity in superdiversity. Working Papers in Urban Language and Literacies, 76. London: King's College.

Bourdieu, P. (1977). The economics of linguistic exchanges. Social Science Information, 16, 645668.

Bourdieu, P. (2008). The bachelors'ball: The crisis of peasant society in Bearn. Chicago: University of Chicago Press. 
Bucholtz, M. (2003). Sociolinguistic nostalgia and the authentication of identity. Journal of Sociolinguistics, 7, 398-416.

Cenoz, J., \& Gorter, D. (2011). A holistic approach to multilingual education: Introduction. Modern Language Journal, 95, 339-343.

Cook, V. (1999). Going beyond the native speaker in language teaching. TESOL Quarterly, 33, 185209.

Cook, V. (2007). The goals of ELT: Reproducing native speakers or promoting multi-competence among second language users? In J. Cummins \& C. Davison (Eds.), International handbook of English language teaching (pp. 237-248). New York: Springer.

Copland, F., \& Creese, A. (2015). Linguistic ethnography: Collecting, analysing and presenting data. London: SAGE.

Coupland, N. (2003). Sociolinguistic authenticities. Journal of Sociolinguistics, 7, 417-431.

Creese, A. (2008). Linguistic ethnography. In K. A. King \& N. H. Hornberger (Eds.), Encyclopedia of language and education: Research methods in language and education (pp. 2nd ed., Volume 10, 229-241). New York: Springer Science + Business Media LLC.

Creese, A. (2010). Linguistic ethnography. In E. Litosseliti (Ed.), Research methods in linguistics (pp. 138-154). London: Continuum.

Creese, A., Bhatt, A., Bhojani, N., \& Martin, P. (2006). Multicultural, heritage and learner identities in complementary schools. Language and Education. 20, 23-43.

Creese, A., \& Blackledge, A. (2010). Translanguaging in the bilingual classroom: A pedagogy for learning and teaching. Modern Language Journal, 94, 103115.

Creese, A., \& Blackledge, A. (2012). Voice and meaningmaking in team ethnography. Anthropology $\mathcal{E}^{\circ}$ Education Quarterly, 43, 306-324.

Doerr, N. M. (2009). Introduction. In N. M. Doerr (Ed.), Native speaker concept: Ethnographic investigations of native speaker effects (pp. 1-12). Berlin: Walter de Gruyter.

Doerr, N. M., \& Kumagai, Y. (2009). Towards a critical orientation in second language education. In N. M. Doerr (Ed.), Native speaker concept: Ethnographic investigations of native speaker effects (pp. 299-318). Berlin: Walter de Gruyter.

Francis, B., Archer, L., \& Mau, A. (2008). British-Chinese pupils' identities, achievement and complementary schooling. Executive report. London: Roehampton University.

Gee, J. P. (1999). An introduction to discourse analysis: Theory and method. London: Routledge.

Gill, M. (2007). Exclusive boundaries, contested claims: Authenticity, language and ideology. In $\mathrm{M}$. Edwards (Ed.), Proceedings of the British Association for Applied Linguistics Conference, 2007 (pp. 41-42). London: Scitsiugnil Press.
Gill, M. (2011). Authenticity. In J.-O. Östman \& J. Verschueren (Eds.), Pragmatics in practice (pp. 4661). Philadelphia/Amsterdam: John Benjamins.

Gill, M. (2012). Nativeness, authority, authenticity: The construction of belonging and exclusion in debates about English language proficiency and immigration in Britain. In C. Percy \& M. C. Davidson (Eds.), The languages of nation: Attitudes and norms (pp. 271288). Bristol, UK: Multilingual Matters.

Heller, M. (1996). Legitimate language in a multilingual school. Linguistics and Education, 8, 139-157.

Holliday, A. (2006). Native-speakerism. ELT Journal, 60, 385-387.

Hymes, D. (1980). Language in education: Forward to fundamentals. Language in education: Ethnolinguistic essays. Language and ethnography series (pp. 139-160). Washington, DC: Center for Applied Linguistics.

Kramsch, C. (1998). Language and culture. Oxford: Oxford University Press.

Kramsch, C. (2012). Authenticity and legitimacy in multilingual SLA. Critical Multilingualism Studies, 1, 107-128.

Kubota, R. (2009). Rethinking the superiority of the native speaker: Toward a relational understanding of power. In N. M. Doerr (Ed.), Native speaker concept: Ethnographic investigations of native speaker effects (pp. 233-248). Berlin: Walter de Gruyter.

Leung, C., Harris, R., \& Rampton, B. (1999). The idealized native speaker, reified ethnicities and classroom realities. TESOL Quarterly, 31, 543-560.

Martin, P., Creese, A., Bhatt, A., \& Bhojani, N. (2004). Final report on complementary schools and their communities in Leicester. Leicester, UK/Birmingham, UK: University of Leicester/University of Birmingham.

Martin-Jones, M., \& Heller, M. (1996a). Introduction to the special issues on education in multilingual settings: Discourse, identities, and power. Part I: Constructing legitimacy. Linguistics and Education, 8, 3-16.

Martin-Jones, M., \& Heller, M. (1996b). Introduction to the special issues on education in multilingual settings: Discourse, identities, and power. Part II: Contesting legitimacy. Linguistics and Education, 8, 127-137.

Maybin, J., \& Tusting, K. (2011). Linguistic ethnography. In J. Simpson (Ed.), Routledge handbook of applied linguistics (pp. 515-528). Abingdon, UK: Routledge.

Mirza, H. S., \& Reay, D. (2000). Spaces and places of black educational desire: Rethinking black supplementary schools as a new social movement. Sociology, 34, 521-544.

No Child Left Behind (NCLB) Act of 2001, Pub. L. No. $107-110$.

Pavlenko, A., \& Blackledge, A. (Eds.). (2004). Negotiation of identities in multilingual contexts. Clevedon, UK: Multilingual Matters.

Phillipson, R. (1992). Linguistic imperialism. Oxford: Oxford University Press. 
Piller, I. (2001). Who, if anyone, is a native speaker? Anglistik. Mitteilungen des Verbandes Deutscher Anglisten, 12, 109-121.

Rampton, M. B. H. (1990). Displacing the 'native speaker': Expertise, affiliation, and inheritance. ELT Journal, 44, 97-101.

Rampton, B. (2007). Neo-Hymesian linguistic ethnography in the United Kingdom. Journal of Sociolinguistics, 11, 584-607.

Scollon, R., \& Scollon, S. W. (2004). Nexus analysis: Discourse and the emerging Internet. London: Routledge.

Silverstein, M. (1976). Shifters, linguistic categories, and cultural description. In K. Basso \& H. Selby (Eds.),
Meaning in anthropology (pp. 11-55). Albuquerque, NM: University of New Mexico Press.

Silverstein, M. (2003). Indexical order and the dialectics of sociolinguistic life. Language and Communication, 23, 193-229.

Talmy, S. (2004). Forever FOB: The cultural production of ESL in a high school. Pragmatics, 14, 149172.

Tusting, K., \& Maybin, J. (2007). Linguistic ethnography and interdisciplinarity: Opening the discussion. Journal of Sociolinguistics, 11, 575-583.

Van Leeuwen, T. (2007). Legitimation in discourse and communication. Discourse $\mathcal{E}^{2}$ Communication, 1, 91112. 